\title{
Hormonal, Metabolic and Cardiovascular Responses to Hypoglycaemia in Type 1 (Insulin-Dependent) Diabetes with and without Residual B Cell Function
}

\author{
S. Madsbad ${ }^{1}$, J.Hilsted ${ }^{2}$, T. Krarup ${ }^{1}$, L. Sestoft ${ }^{1}$, N. J. Christensen ${ }^{3}$, O. K. Faber ${ }^{1}$ and B. Tronier ${ }^{4}$ \\ ${ }^{1}$ Hvidøre Hospital, ${ }^{2}$ Institute of Medical Physiology B, University of Copenhagen, ${ }^{3}$ Medical Department F, Herlev Hospital and \\ ${ }^{4}$ Novo Research Institute, Copenhagen, Denmark
}

\begin{abstract}
Summary. Hormonal, metabolic and cardiovascular responses to insulin induced hypoglycaemia were investigated in seven Type 1 (insulin-dependent) diabetic patients with residual B cell function, eight Type 1 diabetic patients without B cell function and six healthy subjects. No differences were found between the diabetic groups regarding nadir of glucose and rate of recovery to normoglycaemia. The patients with residual B cell function had a glucagon response to hypoglycaemia which was close to that of normal subjects. In patients without B cell function, the glucagon response to hypogly-
\end{abstract}

caemia was present, albeit significantly smaller than in the patients with preserved B cell function $(0.025 \mathrm{ng} / \mathrm{ml}$, range $0.007-0.042$ versus $0.054 \mathrm{ng} / \mathrm{ml}$, range $0.029-0.087$ ). The group without $B$ cell function had signs of an exaggerated rate of lipolysis and ketogenesis compared with the patients with B cell function and the normal subjects.

Key words: Type 1 diabetes, hypoglycaemia, B cell function, glucagon, glucose recovery, lipolysis, ketogenesis.
In normal man plasma concentrations of the counterregulatory hormones (e.g. adrenaline, glucagon, cortisol and growth hormone) increase in response to insulin-induced hypoglycaemia [1, 2]. In normal subjects, glucagon plays a major role in blood glucose recovery after hypoglycaemia $[1,3]$, whereas the role of other counter-regulatory hormones in producing blood glucose recovery has not yet been completely clarified.

Gerich et al. [4] found no plasma glucagon response in Type 1 diabetic patients during hypoglycaemia. Others have demonstrated that in stable insulin-treated Type 2 diabetic patients, unlike 'brittle' Type 1 diabetic subjects, the ability to increase glucagon concentrations during hypoglycaemia persists. Blood glucose recovery is slower in patients with 'brittle' diabetes and there is a blunted glucagon response $[5,6]$.

In Type 1 diabetic patients the relative characteristic of metabolic stability may be due to residual B cell function [5-7]. The aim of the present study was to investigate whether the glucagon response to insulin-induced hypoglycaemia is dependent on residual B cell function in Type 1 diabetes, and, if so, whether the magnitude of glucagon response is related to the rate of blood glucose recovery after hypoglycaemia.

\section{Patients and Methods}

\section{Patients}

Three groups of males were studied. Eight Type 1 patients without residual B cell function (group 1) and seven with residual B cell function (group 2; all were ketosis prone). The clinical characteristics of the diabetic groups are shown in Table 1. In addition six normal subjects were also studied. All were of normal weight with a mean age of 28 years (range 22-34 years) (group 3).

In group 1 , endogenous insulin secretion could not be detected by plasma C-peptide measurements, before and 6 min after an IV injection of $1 \mathrm{mg}$ of glucagon [8]. Group 2 had a mean fasting plasma $\mathrm{C}$ peptide concentration of $0.09 \mathrm{nmol} / 1$ (range $0.06-0.13 \mathrm{nmol} / \mathrm{l}$ ), which increased to $0.15 \mathrm{nmol} / 1$ (range $0.09-0.27 \mathrm{nmol} / \mathrm{l}$ ) 6 min after an IV injection of glucagon. Corresponding values in 18 normal subjects were $0.35 \mathrm{nmol} / 1$ (range $0.25-0.63 \mathrm{nmol} / 1$ ) and $1.20 \mathrm{nmol} / 1$ (range $0.86-1.88 \mathrm{nmol} / 1)$, respectively [8]. Apart from insulin, the patients took no drugs. None of the subjects had signs or symptoms of liver or renal disease. None had any evidence of automatic neuropathy or peripheral neuropathy as judged by beat-to-beat variation in heart rate during deep breathing [9], by orthostatic blood pressure measurement and by vibratory perception threshold [10] (Table 1). In accordance with the Helsinki Declaration, we informed all patients about the purpose and design of the study before obtaining their written consent.

\section{Methods}

Three days before the study, a glucagon test, for evaluation of B cell function, was performed in all the patients. To ensure absence of $\mathrm{SC}$ depots of intermediate acting insulin only soluble insulin was used during the 2 days before admission to hospital. Insulin was taken before main meals and at $22.00 \mathrm{~h}$ in doses adjusted according to urine test results. No patient had ketonuria, and none had subjective symptoms of hypoglycaemia during the last $36 \mathrm{~h}$ before the study. The patients took their last dose of soluble insulin at $17.00 \mathrm{~h}$ on the evening of admission followed by their usual meal at $17.30 \mathrm{~h}$ and a snack at $22.00 \mathrm{~h}$ when admitted to the metabolic ward. An overnight IV insulin infusion was started between $22.00-24.00 \mathrm{~h}$ at an initial rate of $2-4 \mathrm{IU} / \mathrm{h}$. The rate was adjusted according to frequent blood glucose measurements and aimed at achieving a normal blood glucose concentration at $08.00 \mathrm{~h}$. At $08.00 \mathrm{~h}$ hypoglycaemia was induced by IV in- 
Table 1. Clinical characteristics of Type 1 diabetic patients with and without $\mathrm{B}$ cell function

\begin{tabular}{|c|c|c|c|c|}
\hline & \multicolumn{2}{|c|}{$\begin{array}{l}\text { Patients with } \\
\text { B cell function } \\
(n=7)\end{array}$} & \multicolumn{2}{|c|}{$\begin{array}{l}\text { Patients without } \\
\text { B cell function } \\
(n=8)\end{array}$} \\
\hline & Mean & Range & Mean & Range \\
\hline Age (years) & 29 & $21-33$ & 24 & $18-33$ \\
\hline $\begin{array}{l}\text { Duration of } \\
\text { diabetes (years) }\end{array}$ & 3.4 & $0.5-9$ & 4.6 & $2-7$ \\
\hline $\begin{array}{l}\% \text { ideal } \\
\text { body weight }\end{array}$ & 94 & $86-109$ & 101 & $90-109$ \\
\hline $\begin{array}{l}\text { Insulin dose } \\
\quad\left(\mathrm{IU} \cdot \mathrm{kg}^{-1} \cdot \mathrm{day}^{-1}\right)\end{array}$ & 0.48 & $0.29-0.67$ & 0.60 & $0.39-0.72$ \\
\hline $\begin{array}{l}\text { Insulin binding } \\
\text { to } \operatorname{IgG}(\mathrm{U} / 1)\end{array}$ & 0.09 & $0.003-0.234$ & 0.180 & $0.002-0.680$ \\
\hline $\begin{array}{l}\text { Beat-to-beat } \\
\text { variation } \\
\text { (beat } / \mathrm{min} \text { ) }\end{array}$ & 23 & $15-26$ & 22 & $15-33$ \\
\hline $\begin{array}{l}\text { Sense } \\
\text { of vibration }\end{array}$ & 6 & $5-6$ & 7 & $5-11$ \\
\hline
\end{tabular}

fusion of insulin $0.15 \mathrm{IU} \cdot \mathrm{kg}$ body weight ${ }^{-1} \cdot \mathrm{h}^{-1}$. During the insulin infusion period, the blood glucose concentrations were determined by means of a glucose reflectance meter (Eyetone, Ames, Elkhardt, USA). The infusion was stopped when the subjects had symptoms of hypoglycaemia (sweating, dizziness or palpitations).

After an overnight fast the normal subjects were admitted to the metabolic ward at $07.00 \mathrm{~h}$ and rested $1 \mathrm{~h}$ before starting insulin infusion. Blood samples were taken $15 \mathrm{~min}$ before, at the start of induction of hypoglycaemia ( 0$)$ and $30 \mathrm{~min}$ after the start of induction of hypoglycaemia (at the end of insulin infusion) and 15, 30, 60, 90 and 120 min after the end of insulin infusion. Heart rate and blood pressure were measured at the same time intervals using a sphygmomanometer.

A total of $320 \mathrm{ml}$ blood was drawn and the samples were cooled immediately. The plasma was separated within $10 \mathrm{~min}$ and kept below $20^{\circ} \mathrm{C}$. Serum glucose was measured with the hexokinase method [11]. Lactate, pyruvate, glycerol, $\beta$-hydroxybutyrate and acetoacetate were determined using standard enzymatic methods [12]. Serum non-esterified fatty acid (NEFA) was measured colorimetrically [13]. Free insulin was measured after precipitation of insulin binding antibodies with polyethylene glycol $[14,15]$. The sensitivity of the assay is $0.4 \mathrm{mU} / 1$ with a coefficient of variation of 0.04 . Plasma adrenaline and noradrenaline were determined by a double-isotope derivative method [16] with certain modifications [17] and with a sensitivity of 250 pg per sample $(8 \mathrm{ml})$ and a coefficient of variation of $6 \%$. Glucagon was measured with a radioimmunoassay using antibody K5563 which is specific for the C-terminal portion of glucagon [18]. The antiserum employed does not crossreact significantly with enteroglucagon; Sensitivity $0.01 \mathrm{ng} / \mathrm{ml}$ and coefficient of variation 0.05 . Growth hormone was measured by a commercially available solid phase radioimmunoassay kit (Phadebas, Uppsala, Sweden) with a sensitivity of $0.5 \mathrm{mU} / 1$ and a coefficient of variation of 0.05 . Plasma cortisol was measured by a competitive protein-binding technique [19] with a sensitivity of $10 \mathrm{nmol} / 1$ and a coefficient of variation of 0.053 . Insulin binding to IgG was measured by radioimmunoelectrophoresis [20]. Cpeptide was assayed with antibody M1230 [21]. The sensitivity of this assay is $0.03 \mathrm{nmol} / 1$ and the coefficient of variation is 0.05 .

The statistical analyses were performed using Mann-Whitney's rank sum test for unpaired data. Wilcoxon's test comparing paired data and Spearman's rank correlation test to calculate the coefficients of correlation. The level of type I error ( 2 alpha) was set at 0.05 .

The data are presented as mean \pm SEM.

\section{Results}

The time elapsed from the beginning of insulin infusion to hypoglycaemia did not differ significantly between patients with $B$ cell function ( $81 \pm 13 \mathrm{~min}$ ), without $\mathrm{B}$ cell function (92 $\pm 16 \mathrm{~min})$ and normal subjects $(61 \pm$ $8 \mathrm{~min})$.

\section{Glucose, Free Insulin, and C-Peptide Levels}

Blood glucose levels were similar in the two patient groups before induction of hypoglycaemia (Table 2, Fig. 1). The glucose nadirs and rates of glucose recovery were not different between the three groups at any time (Fig.1). Serum glucose concentrations before induction of hypoglycaemia were significantly lower in the normal subjects compared with both patient groups.

Plasma free insulin concentrations were similar in diabetic patients with and without B cell function, whereas the normal subjects had significantly lower plasma free insulin concentrations than the diabetic patients before induction of hypoglycaemia and significantly higher concentrations $120 \mathrm{~min}$ after the end of insulin infusion (Fig. 1).

In the patients with residual B cell function, plasma C-peptide concentration before induction of hypoglycaemia was $0.07 \pm 0.02$ and $0.05 \pm 0.01 \mathrm{nmol} / 1$ at $120 \mathrm{~min}$ (Fig.1). In the normal subjects the average C-peptide concentration was $0.33 \pm 0.01 \mathrm{nmol} / 1$ before induction of hypoglycaemia but only $0.16 \pm$ $0.01 \mathrm{nmol} / 1$ at $120 \mathrm{~min}$ despite no difference in corresponding blood glucose concentrations.

\section{Counter-Regulatory Hormones}

Neither the concentrations nor the incremental areas above baseline of adrenaline, cortisol and growth hormone (Fig. 2) were different in the three groups except for a lower concentration of adrenaline before induction of hypoglycaemia in the group without B cell func-

Table 2. Blood glucose levels during $8 \mathrm{~h}$ before hypoglycaemia in diabetic patients with and without $\mathrm{B}$ cell function

\begin{tabular}{lllllllllll}
\hline & \multicolumn{3}{l}{ Blood glucose levels during $8 \mathrm{~h}(\mathrm{mmol} / \mathrm{l})$} & & & & \\
\cline { 2 - 9 } & 8 & 7 & 6 & 5 & 4 & 3 & 2 & 1 & $1 / 4$ & 0 \\
\hline With B cell function & $13.6 \pm 2.3$ & $13.2 \pm 2.1$ & $10.7 \pm 1.3$ & $10.2 \pm 1.2$ & $9.6 \pm 1.5$ & $8.3 \pm 1.5$ & $7.9 \pm 1.5$ & $5.9 \pm 0.5$ & $6.5 \pm 0.5$ & $6.0 \pm 0.8$ \\
Without B cell function & $14.2 \pm 1.7$ & $14.6 \pm 1.5$ & $12.4 \pm 1.1$ & $11.0 \pm 0.9$ & $9.4 \pm 0.8$ & $7.6 \pm 1.0$ & $6.9 \pm 1.0$ & $6.1 \pm 0.6$ & $7.6 \pm 0.3^{\mathrm{a}}$ & $7.5 \pm 0.4$ \\
\hline
\end{tabular}

Results expressed as mean $\pm \mathrm{SEM}$

a significant differences between the groups. 

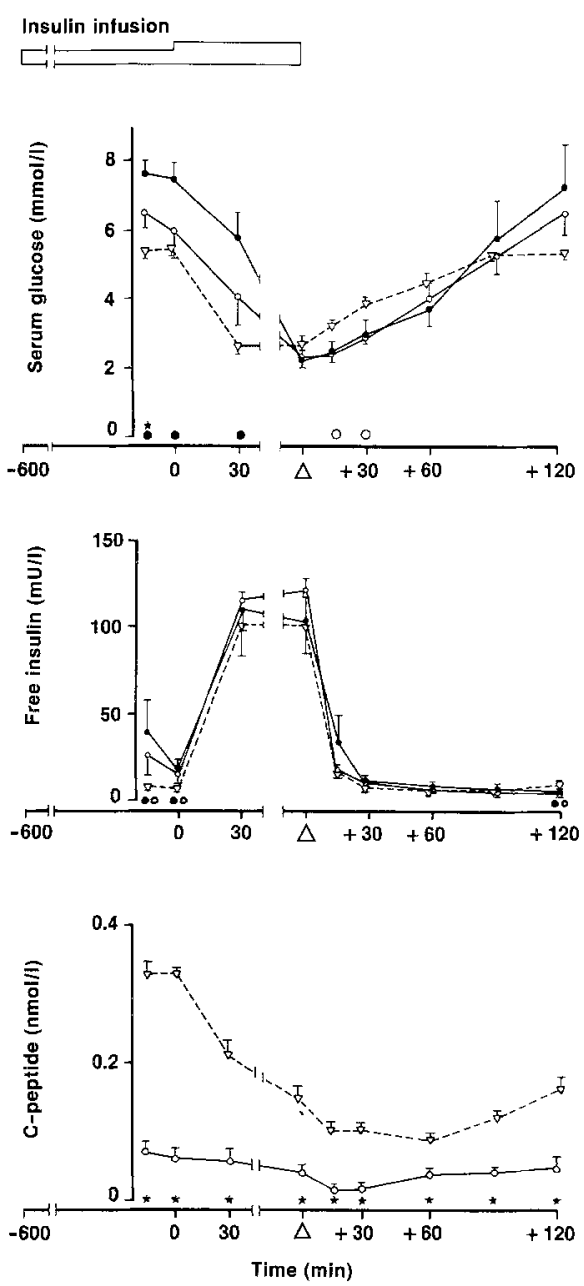

Fig. 1. Serum concentrations of glucose, plasma free insulin and C-peptide concentrations in diabetic patients with $\mathrm{B}$ cell function $(\mathrm{O}-\mathrm{O})$, without $\mathrm{B}$ cell function $(-\mathrm{C})$ and in normal subjects $(\nabla--\nabla)$. $\star$ significant difference between diabetic groups. $O$ difference between normal subjects and patients with $B$ cell function, difference between normal subjects and patients without $B$ cell function. $\Delta$ denotes end of insulin infusion

tion compared with the group with B cell function. The incremental area of noradrenaline was reduced in the group without B cell function compared with the group with B cell function $(p<0.02)$, but similar to that of normal subjects. In the diabetic subjects maximal values of growth hormone after the end of insulin infusion occurred earlier than in the normal subjects $(p<0.02)$.

Before induction of hypoglycaemia, the glucagon concentration was higher in the diabetic group with residual $B$ cell function than in both the normal subjects and the group with no B cell function (Fig. 2). All patients had a rise in glucagon concentrations during hypoglycaemia. This response, defined as the difference between the basal level and the maximal value in each patient, was significantly reduced in the group without $B$ cell function (mean $0.025 \mathrm{ng} / \mathrm{ml}$, range $0.007-0.042 \mathrm{ng} / \mathrm{ml}$ ) when compared with that in the group with preserved B cell function $(0.054 \mathrm{ng} / \mathrm{ml}$, range $0.029-0.087 \mathrm{ng} / \mathrm{ml} ; p<0.01$ ) and normal subjects $(0.098 \mathrm{ng} / \mathrm{ml}$, range $0.035-0.148 \mathrm{ng} / \mathrm{ml})$. Glucagon
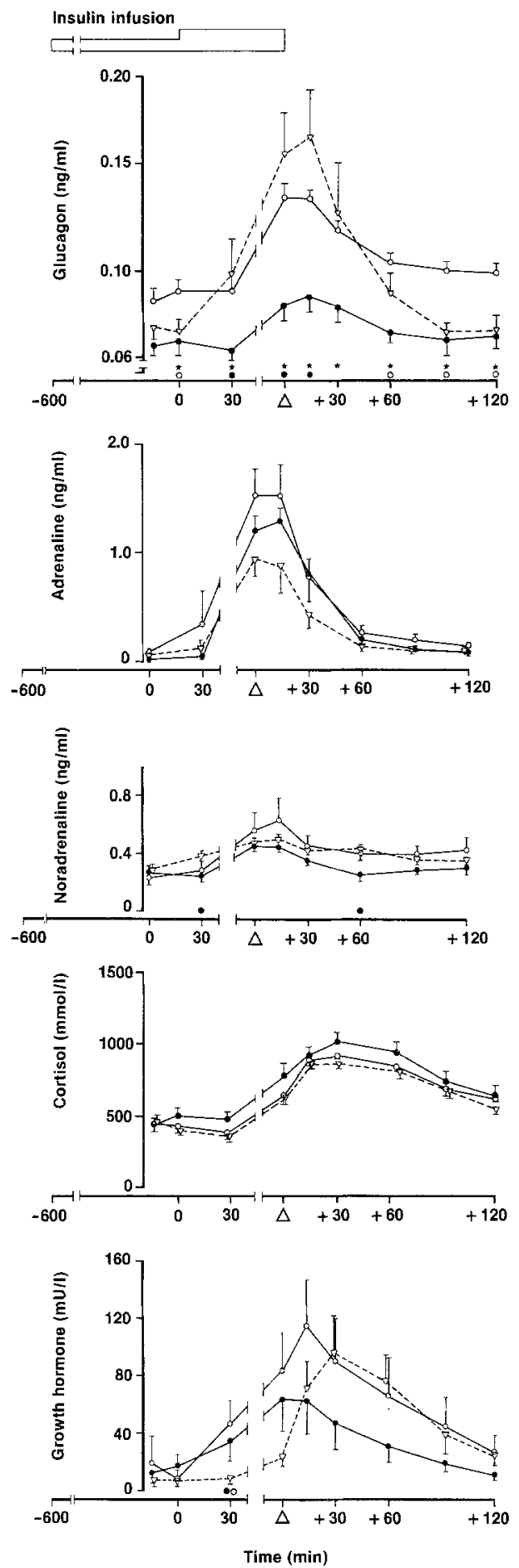

Fig. 2. Plasma concentrations of glucagon, adrenaline, noradrenaline, cortisol and growth hormone in diabetic patients with $\mathrm{B}$ cell function $(\mathrm{O}-\mathrm{O})$, without $\mathrm{B}$ cell function $(-\mathrm{C})$, and in normal subjects $(\nabla--\nabla)$. $\star$ significant difference between diabetic groups. $O$ difference between normal subjects and patients with $B$ cell function, difference between normal subjects and patients without $B$ cell function. $\Delta$ denotes end of insulin infusion

responses were also, evaluated from the incremental areas, greater in the group with B cell function (threefold, $p<0.001$ ). The basal glucose levels did not correlate significantly with the glucagon responses in the diabetic patients $(r=-0.29)$. 
Table 3. Plasma concentrations of NEFA, glycerol, $\beta$-hydroxybutyrate and acetoacetate in patients with and without B cell function and in normal subjects during hypoglycaemia

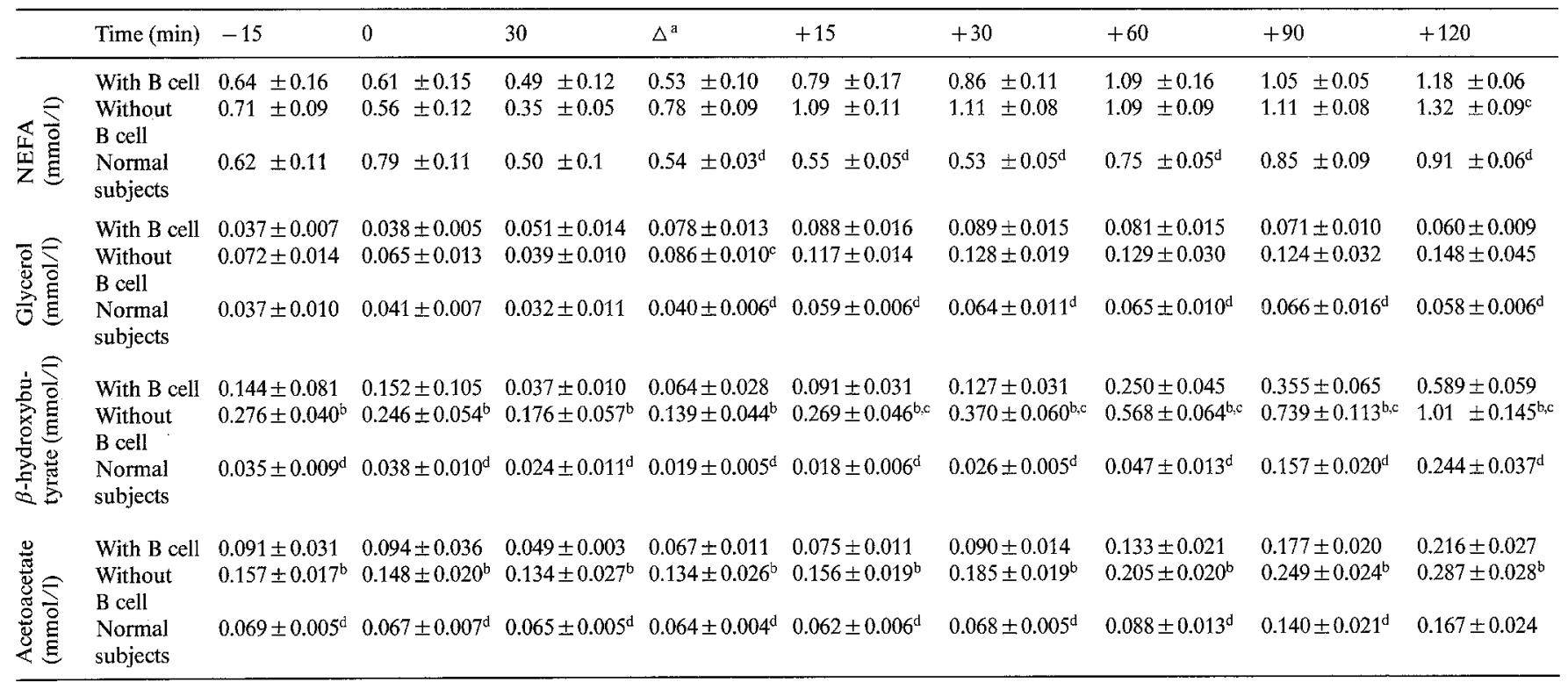

a refers to end of insulin infusion; ${ }^{b}$ significant difference between diabetic groups; ${ }^{c}$ difference between normal subjects and patients with $B$ cell function; ${ }^{d}$ difference between normal subjects and patients without $B$ cell function

\section{Metabolites}

The concentrations of $\beta$-hydroxybutyrate and acetoacetate were higher in the group without B cell function throughout the study (Table 3). From 30 min after stopping insulin, a decline in glycerol concentration was seen in the patients with $B$ cell function, whereas the reverse occurred during the study period in patients without B cell function. No difference in NEFA concentration occurred (Table 3).

The concentrations of lactate and pyruvate did not differ between the diabetic groups except at 90 and $120 \mathrm{~min}$; when the group with residual B cell function had lower lactate concentrations $(p<0.05)$.

\section{Cardiovascular Variables}

The heart rate was not different in the three groups during the study period. The increase in systolic blood pressure was greater and the values after hypoglycaemia were higher in the group without $B$ cell function when compared to patients with B cell function $(p<$ 0.05 ) except at $120 \mathrm{~min}$.

\section{Discussion}

This study shows there is a reduction in glucagon response to hypoglycaemia in Type 1 diabetic patients without residual $B$ cell function compared with patients with residual $\mathrm{B}$ cell function. The exact mechanism by which hypoglycaemia stimulates glucagon secretion has not been established. Previous metabolic control, auto- nomic nervous activity and A cell glucoreceptors have all been suggested as modulators of glucagon response to hypoglycaemia in diabetes. In this study all the patients were treated similarly with fast acting insulin for $48 \mathrm{~h}$ before the study; and during the last $10 \mathrm{~h}$, when IV insulin infusion was used a comparable degree of glycaemic control was achieved in both groups. At $08.00 \mathrm{~h}$ before induction of hypoglycaemia, near-normal blood glucose levels were obtained and no correlation was demonstrated between basal glucose levels and glucagon responses in the diabetic patients. Ensinck and Kanter [22] have also found the same glucagon response to hypoglycaemia before and after $24 \mathrm{~h}$ of normoglycaemia in Type 1 diabetic patients. It would seem that differences in glycaemic control cannot explain the glucagon results.

Maher et al. [23] showed that the glucagon response to hypoglycaemia was absent in patients with autonomic neuropathy. In accordance with this, we have also found no glucagon response to hypoglycaemia in 10 Type 1 diabetic patients with autonomic neuropathy [24]. Several reports have demonstrated that the sympathetic nervous system is of minor or no importance for the glucagon response to hypoglycaemia [25, 26]. Parasympathetic activity has been held responsible for glucagon release [24]. Thus, impaired glucagon release in the patients without $B$ cell function might be due to parasympathetic neuropathy. However, our patients had no signs of vagal defects as evaluated from beat-tobeat variation of heart rate during hyperventilation.

Gerich et al. [4] proposed that the absent glucagon response to hypoglycaemia is caused by an A cell glucoreceptor defect. In the light of the high insulin concen- 
trations obtained during hypoglycaemia, the present study supports the concept that A cell unresponsiveness in Type 1 diabetic patients may be due to a glucoreceptor defect rather than insulin lack. The mechanisms of A-B cell interaction explaining this is unknown. The reports from Shima et al. [5] and Reynold et al. [6] demonstrating an almost normal glucagon response to hypoglycaemia in insulin-treated Type 2 diabetic patients, supports the importance of residual B cell function, for the glucagon response to hypoglycaemia.

Thus the glucagon response to hypoglycaemia in Type 1 diabetic patients demonstrates a range from nearly normal values in patients with residual $B$ cell function compared with an absent response in patients with overt autonomic neuropathy and with no B cell function [24]. Intermediate responses are seen in patients without neuropathy and no B cell function. The exact physiological mechanisms responsible for this diversity of response remain to be established.

In our study the nadir and rate of glucose recovery were identical in the diabetic patients with and without B cell function despite the differences in glucagon responses. This is in accordance with recent experiments suggesting that glucose counter-regulation in man is impaired only if glucagon and adrenaline responses are impaired [27].

Despite similar peripheral free insulin concentrations, the rate of lipolysis as expressed by glycerol concentrations and rate of ketogenesis were relatively normal in the group with residual B cell function. This difference could be due to higher portal insulin levels in patients with residual $\mathrm{B}$ cell function.

Acknowledgements. The authors wish to thank A.Thorburn and L. Kall for skilled technical assistance. The study was supported in part by grants from the Danish Medical Research Council, and Dr. med. E. Gardes and E. Gardes Legat.

\section{References}

1. Rizza RA, Cryer PE, Gerich JE (1979) Role of glucagon, catecholamines, and growth hormone in human glucose counterregulation. J Clin Invest 64: 62-71

2. Gerich JE, Schneider V, Dippe SE, Langlois M, Noacco C, Karam $\mathrm{JH}$, Forsham PH (1974) Characterization of the glucagon response to hypoglycemia in man. J Clin Endocrinol Metab 38: $77-82$

3. Gerich J, Davis J, Lorenzi M, Rizza R, Bohannon N, Karam J, Lewis S, Kaplan R, Schultz T, Cryer P(1979) Hormonal mechanisms of recovery from insulin-induced hypoglycemia in man. Am J Physiol 236: 380-385

4. Gerich JE, Langlois M, Noacco C, Karam JH, Forsham PH (1973) Lack of glucagon response to hypoglycemia in diabetes: Evidence for an intrinsic pancreatic alpha cell defect. Science 182: 171-173

5. Shima K, Tanaka R, Morishita S, Tarui S, Kumahara Y, Nishikawa $M$ (1977) Studies on the etiology of brittle diabetes. Diabetes 26: 717-725

6. Reynolds C, Molnar GD, Horwitz DL, Rubenstein AH, Taylor WF, Jiang N (1977) Abnormalities of endogenous glucagon and insulin in unstable diabetes. Diabetes $26: 36-45$
7. Madsbad S, Alberti KGMM, Binder C, Burrin JM, Faber OK, Krarup T, Regeur L (1979) Role of residual insulin secretion in protecting against ketoacidosis in insulin-dependent diabetes. $\mathrm{Br}$ Med J 2: 1257-1259

8. Faber OK, Binder C (1977) C-peptide response to glucagon. A test for the residual beta-cell function in diabetes mellitus. Diabetes 26: 605-610

9. Hilsted J, Jensen SB (1979) A simple method for determination of autonomic neuropathy in juvenile diabetes. Acta Med Scand 205: 385-387

10. Jersild M, Lauritzen E (1957) Sensibilité vibratoire chez les diabetiques. Diabete 6: 237-241

11. Schmidt FH (1961) Die enzymatische Bestimmung von Glucose und Fructose nebeneinander. Klin Wochenschr 39: 1244-1247

12. Bergmeyer HU (1974) Methods in enzymatic analysis. Academic Press, New York London

13. Novak M (1965) Colometric ultramicro method for the determination of free fatty acids. J Lipid 6: 431

14. Heding LG, Kasperska-Czyzykowa T (1980) C-peptide and proinsulin after oral glucose. Acta Med Scand (Suppl 639): 33-36

15. Nakagawa S, Nakayama H, Sasaki T, Yoshino K, Yu UY, Shinozaki K, Aoki S, Mashimo K (1973) A simple method for the determination of serum free insulin levels in insulin-treated patients. Diabetes 22: 590-600

16. Engelman K, Portney B (1970) A sensitive double-isotope derivate assay for norepinephrine and epinenephrine. Circ Res 26: 53-57

17. Christensen NJ (1971) Plasma noradrenaline and adrenaline in patients with thyrotoxicosis and myxoedema. Clin Sci 45: $163-171$

18. Heding LG (1971) Radioimmunological determination of pancreatic and gut glucagon in plasma. Diabetologia 7:10-15

19. Kehlet H, Binder C, Engbaek C (1974) Cortisol binding capacity in plasma during anaesthesia and surgery. Acta Endocrinol 75: 119-124

20. Christiansen AH (1973) Radioimmunoelectrophoresis in the determination of insulin binding to $\mathrm{IgG}$. Methodological studies. Horm Metab Res 5: 747-754

21. Faber OK, Markussen J, Naithani VK, Binder C (1976) Production of antisera to synthetic benzyloxycarbonyl-C-peptide of human proinsulin. Hoppe Seyler's Z Physiol Chem 357: 751-757

22. Ensinck JW, Kanter RA (1980) Glucagon responses to hypoglycaemia in Type 1 diabetic men after 24-hour glucoregulation by glucose-controlled insulin infusion. Diabetes Care 3: 285-289

23. Maher TD, Tanenberg RJ, Greenberg BZ, Hoffman JE, Doe RP, Goetz FC (1977) Lack of glucagon response to hypoglycemia in diabetic autonomic neuropathy. Diabetes 26: 196-200

24. Hilsted J, Madsbad S, Krarup T, Sestoft L, Christensen NJ, Tronier B (1981) Hormonal, metabolic and cardiovascular responses to hypoglycemia in diabetic autonomic neuropathy. Diabetes 30 : 626-633

25. Ensinck, JW, Walter RM, Palmer JP, Brodows RG, Campbell RG (1976) Glucagon responses to hypoglycemia in adrenalectomized man. Metabolism 25: 227-232

26. Palmer JP, Henry DP, Benson JW, Johnsen DG, Ensinck JW (1976) Glucagon response to hypoglycemia in sympathectomized man. J Clin Invest 57: 522-525

27. Cryer PE (1981) Glucose counterregulation in man. Diabetes 30 : 261-264

Received: 28 August 1981

and in revised form: 30 July 1982

Dr. S. Madsbad

Hvidøre Hospital,

Emiliekildevej 1

DK-2930 Klampenborg,

Denmark 